\title{
EVALUATING THE USE OF THE MULTILOCUS GENETIC MARKER "5S RDNA" FOR THE DISCRIMINATION OF DIFFERENT SPECIES OF FAMILY LETHRINIDAE IN RED SEA, EGYPT
}

\author{
Ghada Mohammed-EISherif $^{1}$; Asmaa Galal-Khallaf ${ }^{1}$; Alaa G. M. Osman ${ }^{2}$; \\ Sobhy El-Sayed Hassab El-Nabi ${ }^{1}$; Khaled Mohammed-Geba ${ }^{{ }^{*}}$ \\ ${ }^{1}$ Zoology Department, Faculty of Science, Menoufia University, Menoufia, Egypt \\ ${ }^{2}$ Zoology Department, Faculty of Science, Al-Azhar University (Assiut Branch), Egypt
}

\begin{abstract}
Article History:
Received: 23 June 2020

Revised: 30 June 2020

Accepted: 1 July 2020

Published Online:

3 July 2020

Keywords:

5S rDNA

12S rDNA

Genetic marker

Lethrinidae

PCR

*Correspondence:

Khaled Mohammed-Geba

Zoology Department

Faculty of Science

Menoufia University

Menoufia, Egypt

E-mail:

Khaled.mohammed@icman. csic.es
\end{abstract}

\begin{abstract}
Family Lethrinidae (Sho'our fishes, Shaari fishes) is one of the key families in the Red Sea and Indian Ocean fisheries. Some of its species were recorded in the International Union for Conservation of Nature (IUCN) Red List of species as endangered. In order to develop simple genetic marker that aid their rapid identification, fin clips of four lethrinid species were collected from local fish markets in Hurghada city. These species were Lethrinus lentjan, L. harak, L. microdon, and L. mahsena. DNA was extracted from these samples and subjected to polymerase chain reaction (PCR) amplification for the mitochondrial $12 \mathrm{~S}$ ribosomal RNA (rRNA) and the nuclear 5S rRNA genes. The $12 \mathrm{~S}$ rRNA PCR amplicons were sequenced. GenBank comparison and phylogenetic analysis for the $12 \mathrm{~S}$ rRNA gene sequences resulted in clear identification for the sampled species. Meanwhile, a simple, 2\% agarose gel electrophoresis for the 5S rDNA ran in a low voltage for 2 hours resulted in variable intraspecific patterns. These patterns appeared as 3 PCR bands of approximately 500 base pair (bp) in length for L. lentjan; 2 PCR bands at 500 and 400 bp for L. harak; single PCR band at 500 bp for L. microdon; and 3 bands at about 750, 500, and $400 \mathrm{bp}$ for L. mahsena. Band separation was clear enough. 5S rDNA exhibited an accurate, interspecific, and easyto-use genetic marker for identification of different lethrinid species covered by the current study.
\end{abstract}

\section{INTRODUCTION}

Several protocols have been described for marine species identification due to the growing interest for healthy seafood. Molecular techniques are providing easily accessible surveillance tools for many biological applications, including the certification of the species present in commercial food products ${ }^{[1,2]}$. These markers provided great success for finfish and shellfish species identification, especially for roughly treated food stuffs where only very short, recoverable DNA fragments are still present ${ }^{[3,4]}$. Those small-sized, leftover DNA fragments permitted a new era of DNA fingerprinting through sequencing of short, informative genomic locations that are considered as barcodes $^{[5,6]}$. These barcodes provided valuable tools for authenticating important market species, monitoring biodiversity, detecting 
the biological invasions ${ }^{[7-9]}$, and many other applications.

The $12 \mathrm{~S}$ ribosomal RNA (12S rRNA) mitochondrial gene (i.e. $12 \mathrm{~S}$ rDNA) has been applied extensively as a species marker due to its interspecific sequence variability, mutation rates, and lower, yet adequately conclusive, degeneracy in comparison to the protein-coding mitochondrial genes ${ }^{[3,10]}$. The nuclear 5S rRNA gene exhibits a more complex array in comparison to the mitochondrial $12 \mathrm{~S}$ rDNA. It consists of a highly conserved, 120 base pair (bp) long transcribed area that plays a role in both ribosomal structure stability and peptidyl transferase enhancement ${ }^{[11]}$. This transcribed area is followed by a hypervariable, tandemly arranged, non-transcribed spacer whose length varies among species ${ }^{[11-13]}$. For the best of the authors' knowledge, the 5S rDNA was not tested for discrimination among Egyptian fish species before.

In Egypt, marine capture fisheries contribute 127,821 tons annually, of which 2,157 are coming from a single fish family, which is Lethrinidae (emperors) ${ }^{[14]}$. This fish group exhibits some morphological similarities that basically emerge as adaptation to the surrounding environment and feeding habits, and not only based of interspecific genetic variations $^{[15-17]}$. This may lead to a serious problem for monitoring the real standing situation for the species conservational status, as well as for their proper fisheries management. Therefore, this study aimed to evaluate the efficiency of application of the nuclear, multilocus gene 5S rDNA for discrimination of the key species belonging to the Family Lethrinidae from the Red Sea in Egypt, and validating such efficiency with other marker, i.e. the mitochondrial $12 \mathrm{~S}$ rDNA, that proved a success in such purpose before $^{[10]}$.

\section{MATERIAL AND METHODS Ethical considerations}

The samples were obtained from fishes after being fished, landed, and sold for human consumption. According to the Committee for Animal Ethics of our Faculty, no permits are required to conduct this market-based study.

\section{Collection of samples}

Freshly caught, five samples of each of Lethrinus lentjan, L. harak, L. microdon, and L. mahsena were obtained from local fish markets in Hurghada, the Red Sea (Figure 1).
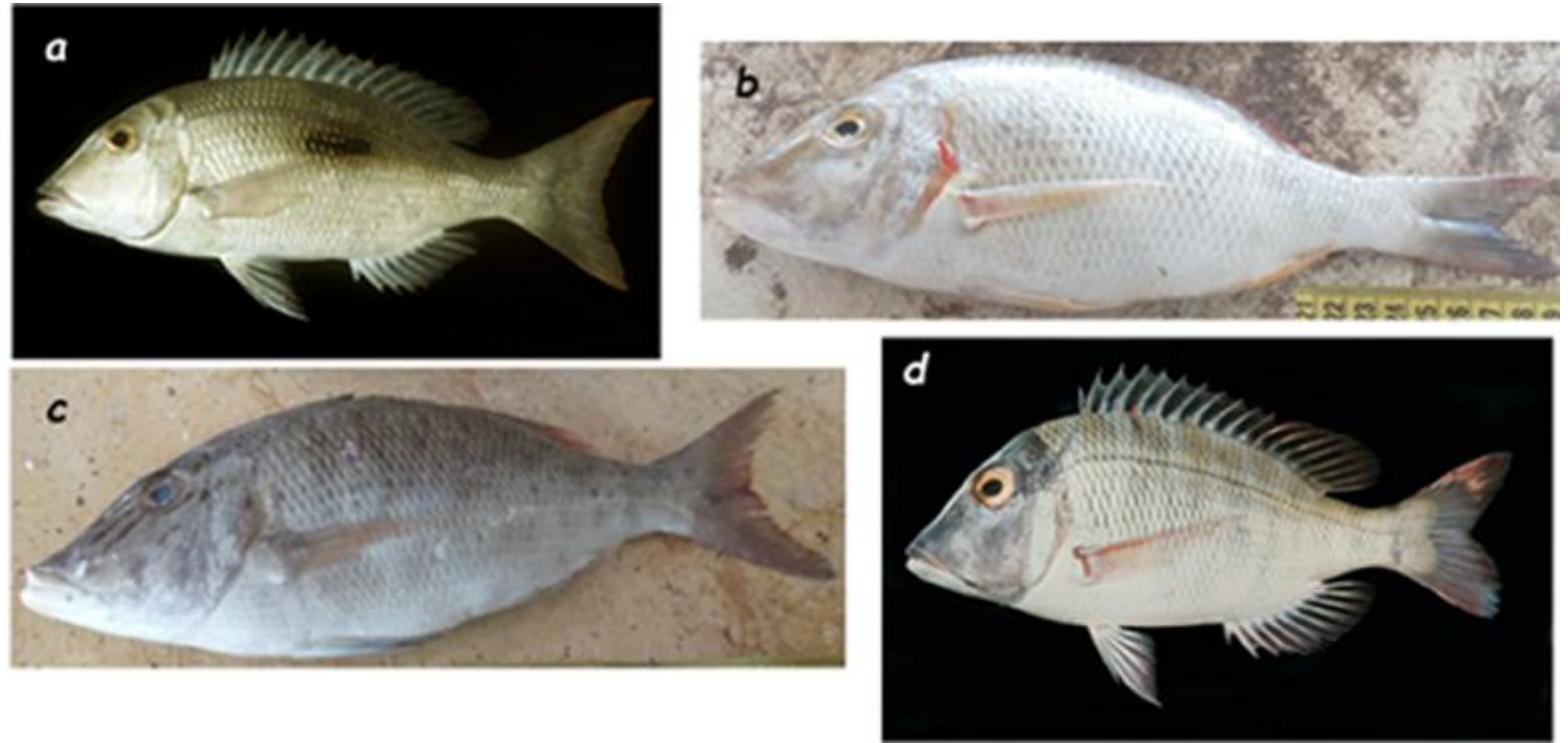

Figure 1: Different emperor species (Lethrinidae) collected from Hurghada city of the Red Sea in Egypt in the current study. (a) Lethrinus harak, (b) Lethrinus lentjan, (c) Lethrinus microdon, and (d) Lethrinus mahsena. 
Fish samples were thoroughly checked for the absence of skin lesions or external parasites. Pectoral fin clips (100 mg) were removed from each fish, placed in $1.5 \mathrm{~mL}$ sterile tubes filled with $70 \%$ ethyl alcohol for preservation, and transferred to our laboratory for genetic analyses.

\section{DNA extraction}

DNA extraction was carried out using the method described in Mohammed-Geba et $a l .{ }^{[18]}$. Briefly, $200 \mu \mathrm{L}$ of TNES-urea buffer with $2.4 \mathrm{U} \mathrm{mL}^{-1}$ proteinase $\mathrm{K}$ solution (ThermoFischer Scientific, Waltham, MA, USA) were added to the individually lysing fins, with incubation at $65^{\circ} \mathrm{C}$. Then, $54 \mu \mathrm{L}$ of $5 \mathrm{~mol} \mathrm{NaCl}$ were added, mixed, and the tubes were centrifuged at $4000 \mathrm{x} g$ for 10 minutes (min). The aqueous supernatant was transferred to a new, sterile tube, and $200 \mu \mathrm{L}$ of freeze-cold isopropyl alcohol were added. After $11000 \mathrm{x} g$ centrifugation for $10 \mathrm{~min}$, the supernatant was replaced by $400 \mu \mathrm{L}$ of $70 \%$ ethanol. The tubes were centrifuged for $5 \mathrm{~min}$ at $11000 \mathrm{xg}$, and then the ethanol was completely removed. Finally, $30 \mu \mathrm{L}$ of Tris-ethylenediaminetetraacetic acid buffer (TE, $\mathrm{pH}=8$ ) were added for DNA pellet resuspension. DNA quality was checked by running in a $1.0 \%$ agarose gel electrophoresis stained with $0.5 \mu \mathrm{g} / \mathrm{mL}$ ethidium bromide (ThermoFisher Scientific).

\section{Polymerase chain reaction (PCR) ampli- fication of 12S rRNA gene}

A hypervariable fragment, 400 bp long, of the mitochondrial $12 \mathrm{~S}$ rDNA was amplified by PCR in each sample. The universal primers described by Palumbi $^{[19]}$ were applied in these PCRs that are: 12SA: 5'-AAACTGGGATTAGAT ACCCCACTAT-3', and 12SF: 5'-GAG GGTGACGGGCGGGCGGTGTGT-3'. The amplification reaction for each sample was set to a total volume of $25 \mu \mathrm{L}$, using $50 \mathrm{ng}$ of template DNA, 1X MyTaq $^{\mathrm{TM}}$ Red Mix (Meridian Life Science, Inc., Memphis, TN, USA), $0.4 \mu \mathrm{mol}$ of each primer, and deionized waters. PCRs were carried out in the thermal cycler Tpersonal (Biometra, Göttingen, Germany). The PCR program applied consisted of an initial denaturation step at $95^{\circ} \mathrm{C}$ for $10 \mathrm{~min} ; 35$ cycles of amplification $\left(1 \mathrm{~min}\right.$ at $95^{\circ} \mathrm{C}$ for denaturation, $1.0 \mathrm{~min}$ at $57^{\circ} \mathrm{C}$ for annealing and $1.0 \mathrm{~min}$ at $72^{\circ} \mathrm{C}$ for extension); and a final extension step of $10 \mathrm{~min}$ at $72{ }^{\circ} \mathrm{C}^{[10]}$. The PCR products were electrophoresed in $1 \%$ agarose gel, and visualized using UV-light (TransillumintorTi1, Biometra). The positive, specific amplicons were sent to Macrogen Inc. (Seoul, South Korea) for conventional Sanger chain termination sequencing method.

\section{PCR amplification of 5S rRNA gene}

For amplifying the 5S rDNA, the universal primers described by Perez and García-Vázquez ${ }^{[20]}$ were applied, that were 5SC: 5'- AAGCTTACAGCACCT GGTATT-3', and 5SMD: 5'-TTCAACATG GGCTCCGACGGA-3'. The amplification reaction was the same as for $12 \mathrm{~S}$ rDNA, but using the following program ${ }^{[20]}$ : initial denaturation at $95^{\circ} \mathrm{C}$ for $5 \mathrm{~min}, 30$ cycles of amplification $\left(20\right.$ seconds at $95^{\circ} \mathrm{C}$ for denaturation, 20 seconds at $65^{\circ} \mathrm{C}$ for annealing and 20 seconds at $72^{\circ} \mathrm{C}$ for extension) and a final extension step of $7 \mathrm{~min}$ at $72^{\circ} \mathrm{C}$. The PCR products were electrophoresed in a $2 \%$ agarose gel, visualized using UV-transillumination, and photographed.

\section{RESULTS}

Sequencing the $12 \mathrm{~S}$ rDNA resulted in good quality sequence chromatograms. GenBank comparisons and ML phylogenetic analysis exhibited close proximity for the sampled species with their references from different areas in the world (Figure 2). L. lentjan (accession number: MT648947) exhibited high sequence identity (Seq. ID) with the ones from Egypt (accession number: KU680994, 99.21\% Seq. ID) and China (accession number: AY484981, 99.21\% Seq. ID). L. harak (accession number: MT648948) was $99.61 \%$ identical to the one from Egypt (accession number: KU680995.1). L. microdon (accession number: MT648949) exhibited $100 \%$ Seq. ID with its reference 


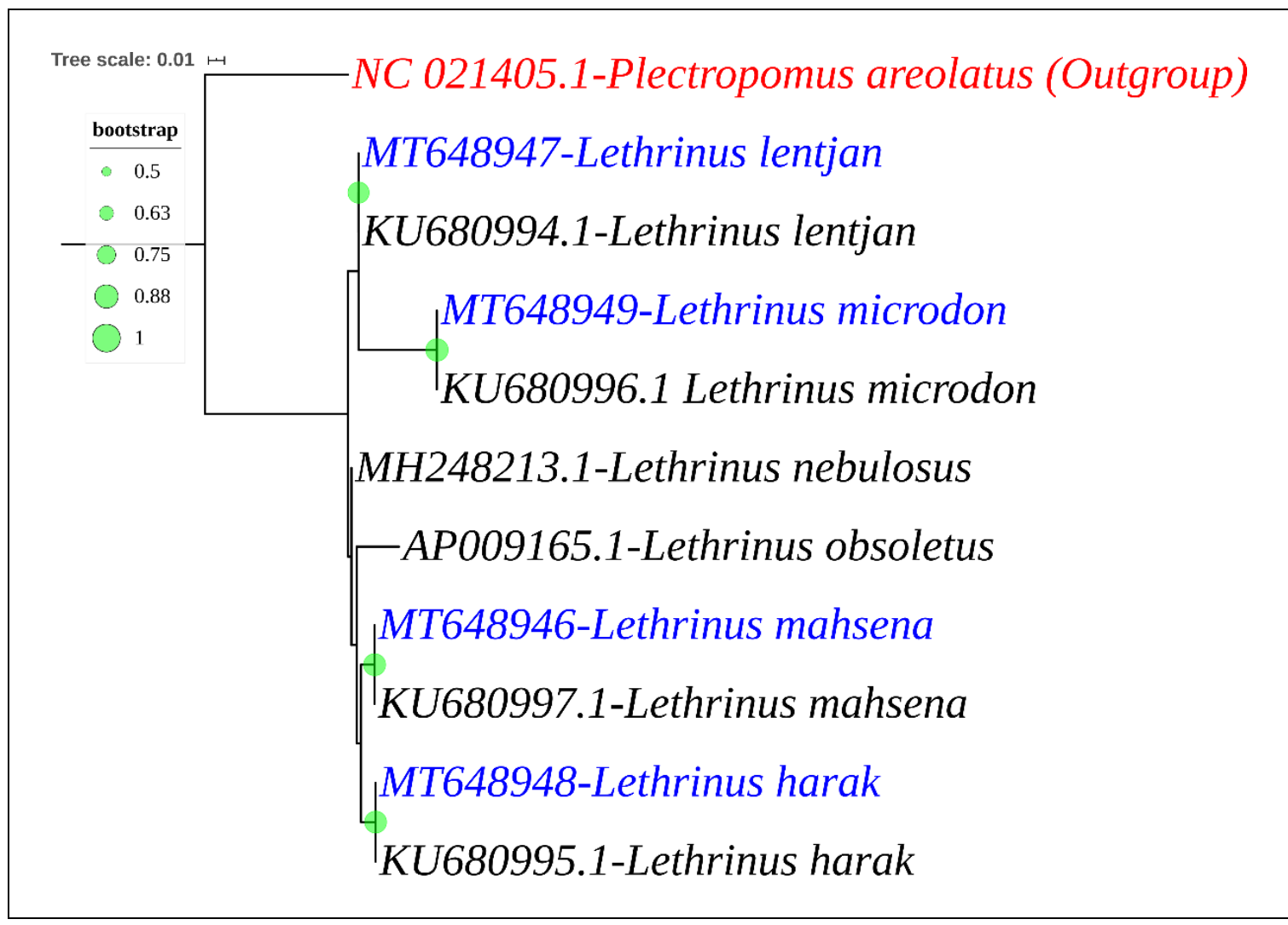

Figure 2: $12 \mathrm{~S}$ rDNA-based maximum likelihood phylogenetic tree for the four studied Lethrinus species (blue color), their GenBank references (black color), and Plectropomus areolatus (Perciformes: Serranidae) as outgroup (red color). Bootstrap values (only above $50 \%=0.5)$ are shown as green circles above the clades.

whose origin was also Egyptian (accession number: KU680996.1). Finally, L. mahsena (accession number: MT648946) was 100\% identical to its GenBank reference (Egypt, accession number: KU680997.1). Phylogenetic analysis, whose best substitution model was Tammura-Nie, with G-value of 0.25 , resulted also in perfect clustering of the assessed species with their GenBank references, with bootstrap values of $>50 \%$ in all cases (Figure 2).

Agarose gel resolution for the 5S rDNA resulted in a conserved band pattern in all samples, regardless to the degree of DNA damage or varying the annealing temperatures. Such pattern was highly species-specific. L. lentjan exhibited 3 PCR bands, one of which was $500 \mathrm{bp}$, and the others were one below and one above the 500 bp. L. harak exhibited double bands that were at 400 and 500 bp. L. microdon samples exhibited a single band close to the size of $500 \mathrm{bp}$. L. mahsena exhibited 3 different bands, the largest of which had the size of $750 \mathrm{bp}$, and 2 smaller bands at 500 and almost 400 bp (Figure 3).

\section{DISCUSSION}

Development of molecular markers for identification and authentication of seafood products has key impacts on conservation and human health ${ }^{[21]}$. In the current study, 4 species from a key fish family in the Egyptian fisheries, i.e. Lethrinidae, could be successfully authenticated using 2 different markers that are the $12 \mathrm{~S}$ rDNA and the 5S rDNA. The 12S rDNA exhibited success in authentication of many fish groups before. In case of lethrinids and related families, $12 \mathrm{Sr}$ DNA sequencing could previously elucidate success in Egyptian Lethrinus species discrimination $^{[10]}$. It was also applied for identifying the phylogenetic relationships among Chinese species from the Family 


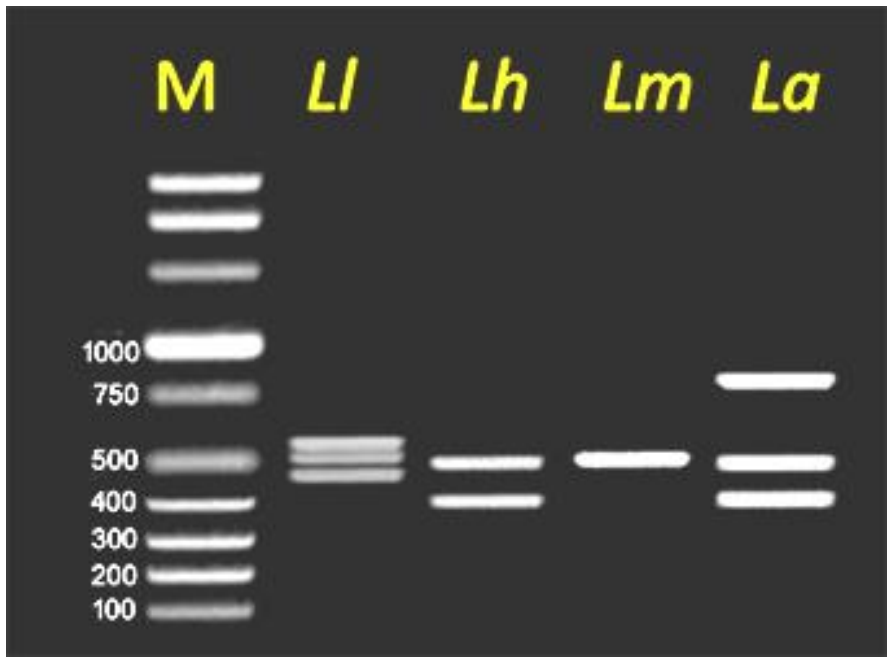

Figure 3: Agarose gel (2\%) electrophoresis for examples for $5 \mathrm{~S}$ rDNA gene of an example from each of the four Lethrinus species analyzed in the current study. Order from left to right is M: DNA size marker, Ll: Lethrinus lentjan, Lh: Lethrinus harak, Lm: Lethrinus microdon, La: Lethrinus mahsena. Band sizes in base pairs (bp) are shown in the left side of the photo.

Lutjanidae $^{[22]}$. It was applied as a marker to detect the prevalence of fishes from the Family Lethrinidae and other families in the subsistence practices of the historic coastal community in southwest Madagascar ${ }^{[23]}$. Moreover, it was applied for biodiversity monitoring and tracking the lethrinids of the Australian waters through their environmental $\mathrm{DNA}^{[24]}$. Hence, this gene exhibited in several cases a good discriminative power for this group of fishes and many others.

In addition to the $12 \mathrm{~S}$ rDNA, application of the 5S rDNA resulted in clear, polymorphic, and species-specific electrophoretic patterns. Application of this protocol for discrimination of Lethrinus spp. exhibited more simple and economic potentials than using a $12 \mathrm{~S}$ rDNA-based protocol. This is directly as the 5S rDNA produced its discriminative pattern after only a simple gel electrophoresis, in contrast to the $12 \mathrm{~S}$ rDNA-based discriminative protocol that could not be completed without sequencing. For small scale food and/or fisheries-specialized inspection laboratories, it may be recommended to apply such markers that reduce time and costs for species and identification. In this sense, Perez and García-Vázquez ${ }^{[20]}$ applied such one-step, electrophoresis-based discriminative 5S rDNA-based protocol to characterize several fish species of the Family Merlucciidae, that were Merluccius paradoxus, M. senegalensis, M. australis, M. gayi, M. bilinearis, M. hubbsi, and
Macruronus magellanicus. Also, Pinhal et $a .^{[12]}$ successfully generated 5S rDNAbased, interspecific electrophoretic patterns from 8 shark species, i.e. Sphyrna lewini, Galeocerdo cuvier, Carcharhinus obscurus, C. leucas, C. limbatus, C. achronotus, Alopias superciliosus, and Isurus oxynchus. De Luna Sales et al. ${ }^{[25]}$ also identified the same $5 \mathrm{~S}$ rDNA patterns for the squids Loligo surinamensis, L. sanpaulensis, Lolliguncula brevis, Sepiotheuthis sepioidea, Ornithoteuthis antillarum, and Illex argentines. However, the application of banding variations in species discrimination may necessitate preliminary trials, as not all species show such interspecific banding. For instance, and in contrast to our findings in the current study and those previously mentioned for other seafood species, Veneza et al. ${ }^{[13]}$ identified intraspecific variations in the electrophoretic bands of the 5S rDNA in species from the Family Lutjanidae.

In conclusion, the 5S rDNA nuclear gene could be proven as a successful marker for discrimination the commonest 4 Lethrinus species in Egypt. The interspecific multiple bands' pattern identified in the agarose gel electrophoresis can recommend the application of this molecular marker in rapid and cost-effective species identification. Despite coupling this marker with $12 \mathrm{~S}$ rDNA gene sequencing results in a more validated methodology, the variable patterns identified for the 
5S rDNA can suggest it as a stand-alone marker for the species tested herein in the current work.

\section{ACKNOWLEDGMENTS}

Authors are grateful to the Lab of Natural Resources, leaded by Prof. Eva GarcíaVázquez (University of Oviedo, Asturias, Spain) that inspired us with the idea of the current work. This research received no specific grant from any funding agency in public, commercial, or not-for-profit sectors.

\section{CONFLICT OF INTEREST}

The authors declare that they have no conflict of interest with the results of the present research.

\section{AUTHORS' CONTRIBUTIONS}

GM-E: investigation, methodology, writing original draft; AG-K: conceptualization, methodology, data curation, writing original draft; AGMO: resources, reviewing original draft; SEHE: supervision, reviewing original draft; KM-G: supervision, conceptualization, software, reviewing original draft.

\section{REFERENCES}

[1] Pérez, M.; Cabado, A. G.; Vieites, J. M. et al. (2004). Experimental assessment of a new rDNA-based method for the identification of Merluccius capensis and Merluccius paradoxus in commercial products. Journal of Aquatic Food Product Technology, 13(2): 49-57.

[2] Duran, C.; Appleby, N.; Edwards, D. et al. (2009). Molecular genetic markers: discovery, applications, data storage and visualization. Current Bioinformatics, 4: 16-27.

[3] Rasmussen, R. S. and Morrissey, M. T. (2008). DNA-based methods for the identification of commercial fish and seafood species. Comprehensive Reviews in Food Science and Food Safety, 7(3): 280-295.

[4] Galal-Khallaf, A.; Osman, A. G.; Carleos, C. E. et al. (2016). A case study for assessing fish traceability in Egyptian aquafeed formulations using pyrosequencing and metabarcoding. Fisheries Research, 174: 143150.

[5] Kress, W. J. and Erickson, D. L. (2008). DNA barcodes: genes, genomics, and bioinformatics. PNAS, 105(8): 2761-2762.

[6] Böhme, K.; Calo-Mata, P.; BarrosVelázquez, J. et al. (2019). Review of recent DNA-based methods for main food-authentication topics. J Agric Food Chem, 67(14): 3854-3864.

[7] Zhao, L.; Dong, J.; Sun, C. et al. (2019). Phylogenetic analysis of sooty grunter and other major freshwater fishes in the suborder Percoidei based on mitochondrial DNA. Mitochondrial DNA Part A, 30(2): 234-248.

[8] Rüber, L.; Tan, H. H. and Britz, R. (2020). Snakehead (Teleostei: Channidae) diversity and the Eastern Himalaya biodiversity hotspot. Journal of Zoological Systematics and Evolutionary Research, 58: 356-386.

[9] Borrell, Y. J.; Miralles, L.; Do Huu, H. et al. (2017). DNA in a bottle-Rapid metabarcoding survey for early alerts of invasive species in ports. PloS One, 12(9): e0183347 (DOI: 10.1371/ journal.pone.0183347).

[10] Galal-Khallaf, A.; Mohammed-Geba, K.; Osman, A. G. et al. (2017). SNP based PCR-RFLP, T-RFLP and FINS methodologies for the identification of commercial fish species in Egypt. Fisheries Research, 185: 34-42.

[11] Castro, S. I.; Hleap, J. S.; Cárdenas, H. et al. (2016). Molecular organization of the 5S rDNA gene type II in elasmobranchs. RNA Biol, 13(4): 391399.

[12] Pinhal, D.; Gadig, O. B.; Wasko, A. P. et al. (2008). Discrimination of shark species by simple PCR of 5S rDNA repeats. Genet Mol Biol, 31: 361-365.

[13] Veneza, I.; Felipe, B.; Oliveira, J. et al. (2014). A barcode for the authentication of the snappers (Lutjanidae) of the western Atlantic: 
rDNA 5S or mitochondrial COI? Food Control, 38: 116-123.

[14] Fishery and Aquaculture Country Profiles, Egypt (2010). Country profile fact sheets. In: FAO Fisheries and Aquaculture Department, Rome, Italy (http://www.fao.org/fishery/facp/EGY).

[15] Lo Galbo, A. M.; Carpenter, K. E. and Reed, D. L. (2002). Evolution of trophic types in emperor fishes (Lethrinus, Lethrinidae, Percoidei) based on cytochrome $b$ gene sequence variation. J Mol Evol, 54(6): 754-762.

[16] Carpenter, K. E. and Randall, J. E. (2003). Lethrinus ravus, a new species of emperor fish (Perciformes: Lethrinidae) from the western Pacific and eastern Indian oceans. Zootaxa, 240: $1-8$.

[17] Thi, O. T.; Ha, Q. V. D. and Thuy, B. D. (2015). Phylogenetic relationships of emperors (Lethrinidae) and Snappers (Lutjanidae) in Vietnam based on mitochondrial DNA sequences. Proceeding of the International Conference on Biological, Environment and Food Engineering (BEFE-2015), Singapore, 15-16 (http://dx.doi.org/10.15242/IICBE.C05 15016).

[18] Mohammed-Geba, K.; Hassab ElNabi, S. E. and El-Desoky, M. S. (2016). Development of cytochrome-coxidase 1 specific primers for genetic discrimination of the European eel Anguilla anguilla (Linnaeus, 1758). Journal of Bioscience and Applied Research, 2(4): 258-262.

[19] Palumbi, S. R. (1996). Nucleic acids II: the polymerase chain reaction.
In: Molecular Systematic (Hillis, D. M.; Mortiz, C. and Mable, B. K., eds), pp. 205-247. Sinauer Associates Inc., Sunderland, MA, USA.

[20] Perez, J. and García-Vázquez, E. (2004). Genetic identification of nine hake species for detection of commercial fraud. J Food Prot, 67(12): 2792-2796.

[21] Jacquet, J. L. and Pauly, D. (2008). Trade secrets: renaming and mislabeling of seafood. Marine Policy, 32(3): 309-318.

[22] Zhang, J. and Liu, X. (2006). The phylogenetic relationship of the Family Lutjanidae based on analyses of AFLP and mitochondrial 12S rRNA sequences. Chinese Science Bulletin, 51: 143-148.

[23] Grealy, A.; Douglass, K.; Haile, J. et al. (2016). Tropical ancient DNA from bulk archaeological fish bone reveals the subsistence practices of a historic coastal community in southwest Madagascar. Journal of Archaeological Science, 75: 82-88.

[24] Stat, M.; Huggett, M. J.; Bernasconi, R. et al. (2017). Ecosystem biomonitoring with eDNA: metabarcoding across the tree of life in a tropical marine environment. Scientific Reports, 7: 12240 (DOI: 10.1038/s41598-017-12501-5).

[25] de Luna Sales, J. B.; da Silva Rodrigues-Filho; L. F., Haimovici, M., et al. (2011). Molecular differentiation of the species of two squid families (Loliginidae and Ommastrephidae) based on a PCR study of the 5S rDNA gene. Food Control, 22: 96-98.

\section{How to cite this article:}

Mohammed-ElSherif, G.; Galal-Khallaf, A.; Osman, A. G. M.; Hassab El-Nabi, S. E. and Mohammed-Geba, K. (2020). Evaluating the use of the multilocus genetic marker "5S rDNA" for the discrimination of different species of Family Lethrinidae in Red Sea, Egypt. Egyptian Journal of Zoology, 74: 22-29 (DOI: 10.12816/ejz.2020.33134.1035). 


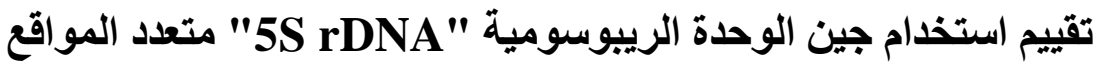

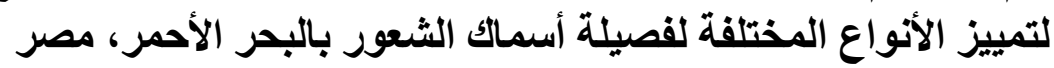

\section{غادة محمد الثريف1، أسماء جلال خلاف1، علاء جاد الكريم عثمان، صبحي السيد حسب النبي؛، خالا محمد جبة الع}

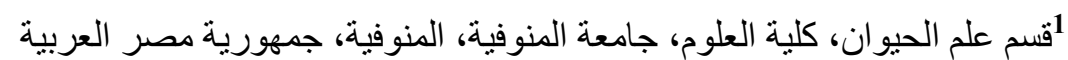

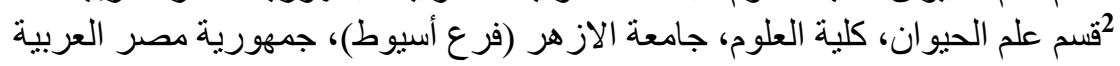

تعد فصيلة أسماك الشعور من الفصائل السمكية الرئيسية في مصايد البحر الأحمر والمحيط الهندي. تم تسجيل بعض التصائ

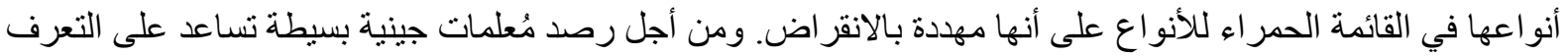

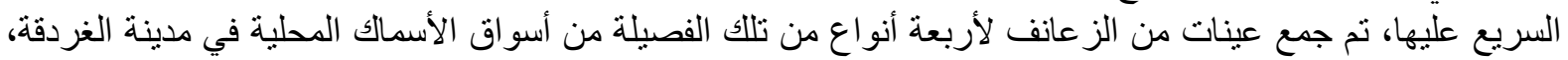

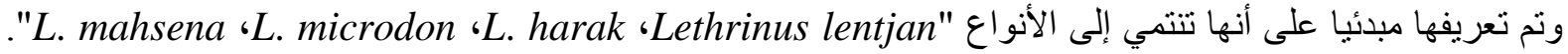

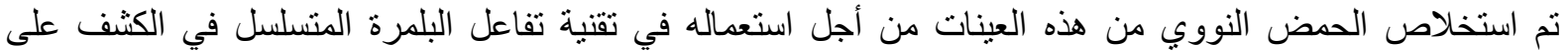

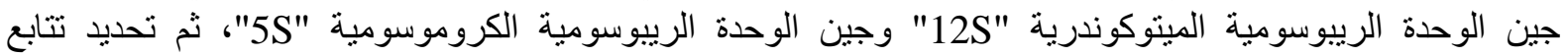

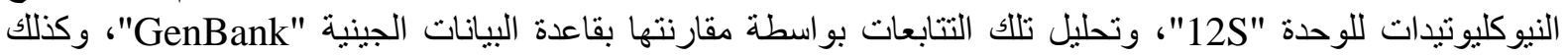

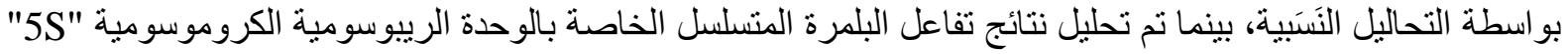

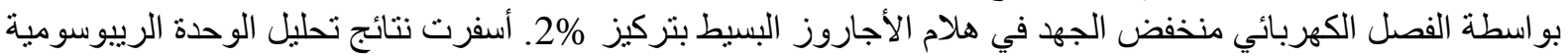

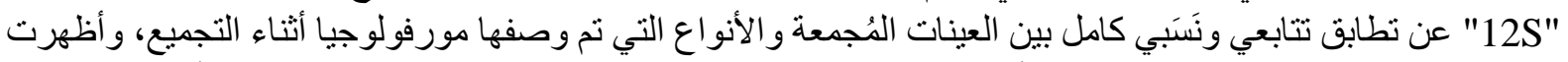

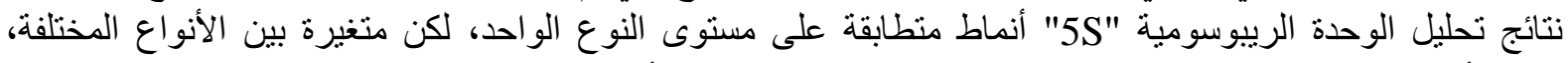

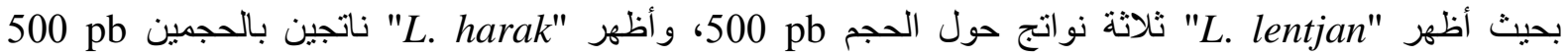

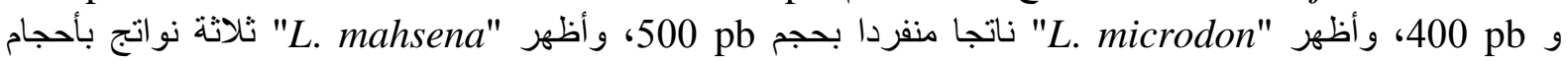

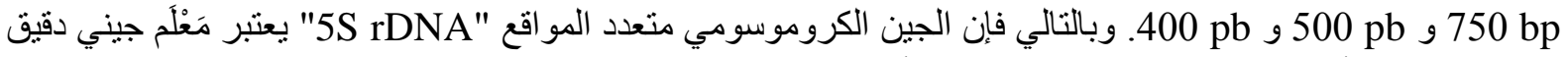

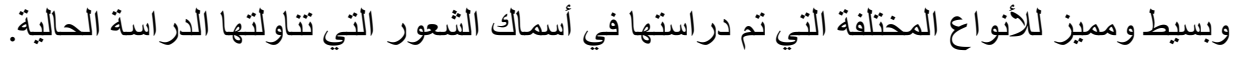

